\title{
THE STORAGE OF FORENSIC EVIDENCE AT THE FORENSIC SCIENCE LABORATORY IN PRETORIA, SOUTH AFRICA
}

\author{
JUANITA VAN DER WALT \\ ROSE LUKE \\ juanitav@uj.ac.za@uj.ac.za \\ Institute of Transport and Logistics Studies (Africa) \\ University of Johannesburg
}

\begin{abstract}
One of the cornerstones of the judicial process is the presentation of evidence in a court of law. The integrity of evidence is vital to reassure the courts that the correct procedures were followed throughout all the processes it was subjected to. In South Africa, the Forensic Science Laboratory (FSL) in Pretoria analyses and stores evidence. The storage facility within the FSL should contribute to the prevention of evidence contamination or degradation thereby also leading to improved service quality and output to its customers. The proper delivery of evidence can lead to the conviction of suspects and to the freedom of the innocent. This study investigates the storage facilities at the FSL to determine whether these are appropriate to ensure the integrity of evidence throughout all the processes it goes through and to recommend actions to continue to add value to the judicial system.
\end{abstract}

\section{INTRODUCTION}

One of the cornerstones of the judicial process is the presentation of evidence in a court of law. Physical evidence or real evidence, such as forensic evidence in the form of deoxyribonucleic acid (DNA), is anything that can be perceived with the five senses that tends to prove a fact that is at issue (Hails, 2005). The value of evidence is indisputable; it proves the fact that a crime has been committed or not committed; it serves as a back-up to the testimony of witnesses and links a suspect to the crime in question (Hails, 2005).

DNA, which can consist of any human tissues or fluid such as saliva, semen and hair, is one of the types of evidence that can be collected at a crime scene and later compared to that taken from a suspect (Lehman \& Phelps, 2005). Evidence can therefore link a suspect to a crime or eliminate a person as a suspect (Lerner \& Lerner, 2006a).

Crimes can take many forms and establishing how and who committed the crime depends on highly skilled people and specialised processes and facilities (Fowler, 2006). This link between the crime and the perpetrator is often established through DNA analysis at a 
forensic laboratory. In the process, however, this evidence passes along an evidence chain and evidence goes through various storage activities before, during and after analysis. The investigation of a crime is therefore multi-disciplinary and depends on the effective and efficient collection and management of evidence.

The integrity of evidence is vital to reassure the courts that the correct procedures were followed throughout all the processes it is subjected to. In South Africa, the Forensic Science Laboratory (FSL) in Pretoria analyses and stores evidence. Evidence should be kept, as far as possible, in its original form and should be documented through the various stages in the chain, from identifying the evidence, through collection, packaging and transportation to the FSL. The flow of the evidence from the crime scene to the courts must be validated by ensuring that contamination did not take place at any point along the evidence supply chain including the collecting, handling and documenting thereof. This is also known as the chain of evidence (Lerner \& Lerner, 2006b). The evidence chain can be equated to a supply chain and is illustrated in Figure 1. This diagram shows all the processes that physical evidence must go through from the moment the crime scene is discovered until the time the evidence collected at the crime scene(s) is presented in court. For the purposes of this paper, only the processes at the warehouse (FSL) are discussed.

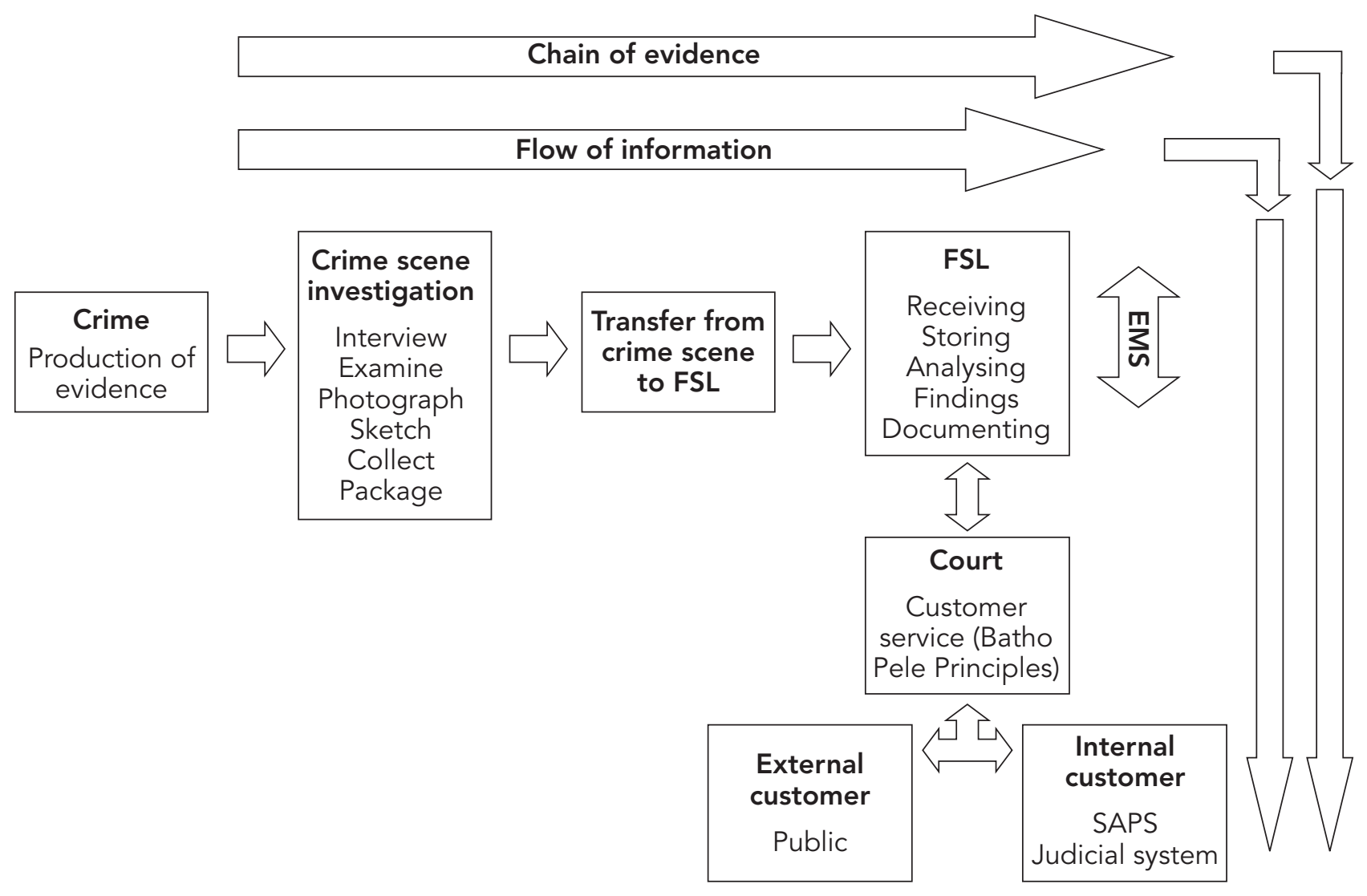

Figure 1: Evidence supply chain (Compiled for the purpose of the study) 
Warehousing plays an important role in providing customers with the right product at the right time and place in the right condition when the customer requires it. This includes the storage of raw materials, in-process inventory, finished goods, specialised items such as DNA, services and related information (Helms, 2006a). It also includes the receiving of goods and the registering, packing, picking and eventual shipping of the goods to the final customer (Heragu, Cai, Krishnamurthy \& Malmborg, 2008). Warehousing plays a key role in the management of goods, in this instance evidence, by storing items in a secure facility and through various activities, providing it at the time the judicial system (the customer) requires them.

The storage facility within the FSL should contribute to the prevention of evidence contamination or degradation thereby also leading to improved service quality and output to its customers. The proper delivery of evidence can lead to the conviction of suspects and to the freedom of the innocent. The warehousing activities carried out by the FSL thus need to be performed in the most efficient way possible to add value to the flow of evidence and the judicial system overall.

Although evidence includes all information gathered at a crime scene by an investigator and includes physical and testimonial evidence, this study focuses only on DNA evidence and its supply chain and is limited to the FSL's Biology Section (referred to as the FSL) situated in Pretoria, which specifically deals with DNA evidence.

\section{RESEARCH METHODOLOGY}

Various sources of data and methods of data collection were used for the research. The methods of data collection were based on their applicability to the aspects covered by the study. The research approach and methodology included an analysis of the available literature, the examination of case studies, informal discussions, personal and structured interviews and personal observations. A pragmatic approach with regard to these methodologies was followed by combining the outcomes of each, allowing for the formulation of valid conclusions and recommendations.

A literature review and study of the concepts 'evidence, warehousing, customer service and information flow' in general was done, followed by a study of the FSL as a storage facility. Newspaper articles were also used, which outlined problems and issues surrounding evidence and storage. These literature analyses formed the basis of the informal interviews and case studies.

Generalised and specialised warehousing, customer service and information flow concepts were used as benchmarks for the FSL storage facility. The researchers' conclusions were 
based on the research into these concepts, specifically with reference to the evidence supply chain, which serves to explain the possible improvements to the FSL as a storage facility.

Various case studies were analysed to explain the complex issues surrounding DNA evidence and the purpose of forensic laboratories. Real-life events, situations and issues highlighted the advantages of preserving DNA appropriately and the successes experienced due to the use of forensic evidence. The case studies supported the objectives of the study.

Informal interviews and discussions with the staff and head of the FSL Biology Section in Pretoria were conducted to understand various practical aspects of the FSL storage facilities. Respondents were encouraged to talk freely about the subject and were generally not bound by specific questions.

In the more formal interviews, a structured questionnaire was used to obtain specific information regarding the FSL, evidence, receipt of evidence, storage of evidence, key issues, physical inventory and cycle counting, audits, evidence analysis, procedures and reports, laboratory needs, information technology, facilities and customer service. This also addressed the specific needs of the FSL with regard to their current facilities as an integral part of the evidence chain.

\section{THE ROLE OF EVIDENCE IN THE JUDICIAL VALUE CHAIN}

Evidence is the product of a crime and is used to link a suspect to a crime. Physical evidence is 'something legally submitted to a competent tribunal as a means of ascertaining the truth of any alleged matter of fact under investigation before it' (SCCJA, n.d.).

Hails (2005) explains physical or real evidence as anything that is physically tangible, in that it can be perceived using sight, where this may be macroscopic, microscopic or trace elements, whether at the time of investigation or before the crime is committed, and physically movable items. These tend to prove a certain elemental uncertainty within reasonable doubt to be true, or conversely, false. Physical evidence, specifically DNA, is useful in helping to establish the scope of a crime scene, such as placing a suspect at a scene and establishing a connection with a weapon, an area and the testimonies of witnesses.

The manner in which evidence is processed will influence the role it is able to play in solving a particular crime. The validity of the evidence depends on the care taken by the investigator collecting it and the FSL in storing it, to protect it against contamination. Improper collection, handling or storage may destroy its value to the judicial system. The 
manner in which evidence is collected has a direct influence on the integrity of the evidence (Bennet \& Hess, 2004).

Preservation of the integrity of physical evidence is a continuous responsibility from the time it is discovered until the time it is presented in court or until the final settlement of the case determines its disposal. To ensure that physical evidence is accepted in court, proof concerning its location, condition and connection with the crime scene is essential. The correct handling of physical evidence is critical as the court must be convinced that the evidence was not altered or tampered with at any time (Evert, 2008).

When DNA is collected, stored and transported appropriately, it could be preserved for years (Anonymous, 2003). However, environmental factors such as heat, moisture and water can break down the chemical structure of DNA (DNA Initiative, n.d.). DNA should be kept dry and preferably at room temperature to prevent degradation as these factors can affect the integrity of DNA (Lee \& Roberts, 2008). Appropriate storage is thus critical to the success of evidence in the judicial system.

\section{THE FORENSIC SCIENCE LABORATORY (FSL) BIOLOGY SECTION: STORAGE PROCESSES}

Coetzee and Horn (2007) define the role of the FSL as being 'responsible for forensic science support to the SAPS. This support includes many specialised services in the fields of biology, chemistry, explosives, ballistics, etc.'

The FSL facility is government-owned and forms part of the South African judicial system. This facility allows for flexibility in its operations and the fulfilment of specialised functions such as long-term storage of DNA evidence. The Biology Section deals with DNA evidence which could easily be destroyed by contamination or degradation. DNA is a fragile product and thus requires specialised methods for its handling, storing and analysis.

The FSL receives all incoming evidence and must prevent contamination, theft or loss, and maintain and update all documentation relating to the evidence. All information related to the evidence is stored in the Exhibit Management System (EMS) and can be retrieved at any time (Hennop, 2009). Therefore the evidence can be tracked at all times while it is in the chain of evidence. Lerner and Lerner (2006b) recognise the importance of documenting the chain of evidence at forensic laboratories and indicate this as follows:

'... All forensic laboratories must maintain a documented system in which they demonstrate their level of quality ... Specific guidelines are provided on the organisation and management 
of the lab; training level and method of training staff; facilities; control of evidence, including the complete documentation of the chain of evidence; the methods, analysis, and validation process; equipment maintenance; review process; proficiency testing; corrective action; and audits.'

All storage activities that take place at the FSL must ensure the chain of evidence.

The FSL ensures that all evidence is properly documented and stored. Every time anyone deals with evidence it must be documented, and these various documentations form the chain of evidence that shows the integrity of the evidence. Interim releases of evidence to court, to the laboratory for analysis or to other sections are updated on the EMS to ensure the chain of evidence. All information and documentation recorded must be current and accurate to satisfy any court in the judicial system (Hennop, 2009).

The duties of the receiving personnel are to physically check each shipment of evidence against the investigator's inventory. Discrepancies should be recorded in writing and reported immediately (Hennop, 2009). Signing the evidence receipt represents the acceptance of the evidence and signifies that all evidence received was verified and that all containers, packages and documents had the proper case numbers attached. The receiving function thus establishes an effective audit trail for new evidence received into the system (Hennop, 2009).

The Case Registration Official (CRO) takes delivery of the evidence and verifies the items against the receiving minute containing a list of the evidence. Items can either be accepted or rejected. If there is more than one piece of evidence in a case, each item is sealed separately and if necessary, all items in the case are collected together in a bigger package (Hennop, 2009). Should the evidence be accepted, it continues to the processes of registration, marking, packaging and storage (Hennop, 2009).

A case file is printed for each case and combined with the correct minutes of that case file. After the EMS registration has been done, barcode labels are printed and attached to the case file and evidence (Hennop, 2009). The case files and evidence are handed over to the quality control official who checks against aspects such as the covering minute, crime scene attendance document, acknowledgement of receipt and internal transfer document for correctness.

After quality control is completed, the evidence is handed to the storage official and is stored according to category. The evidence is packed in a specific position in the storage area and the location is updated on the EMS system. The FSL allocates evidence according to any available storage room space. This forms part of the receiving activity at the FSL (Hennop, 2009). 
Regular checks are performed to ensure the storage, handling and analysis of evidence is done according to pre-determined standards and to ensure that evidence has not been misplaced or gone missing. Each piece of evidence is scanned and processed, a report is drawn up to identify misplaced evidence, and corrective actions could be taken. The evidence is stored until a request to analyse the evidence is received, after which it is allocated to an analyst (Hennop, 2009).

\section{WAREHOUSING PROCESSES}

The term 'warehousing' refers to the storage of goods in an organised and methodical manner which assures the continuous availability of goods when required (Vasiliu 2008). Furthermore, warehousing is no longer concerned with just storing products, but with moving the product, when required, through the facility in a quick and efficient manner (Brockman, 1999).

Grant, Lambert, Stock and Ellram (2006) recognise three basic functions of a warehouse, namely movement, storage and information transfer. Zandin (2001) further divides movement into receiving goods, storing and keeping track of goods, picking the goods when required, and shipping the goods to the consumer. Warehousing also includes managing of inventory in such a manner that costs are reduced; planning of space requirements; establishing innovative storage methods and equipment; and taking layout and design into consideration.

Receiving includes the orderly receiving of goods at the warehouse, inspecting whether these are in the correct quantity and quality, for example, in terms of the accompanying documentation (Grant et al., 2006). The FSL's receiving process includes specific requirements that have to be met at the receiving point, not only to safeguard evidence but to ensure correct handling and recording of the evidence received. This is essential to establish the chain of evidence.

Packaging refers to the materials holding a product or item. The purpose is to facilitate the identification of an item, the avoidance of damage, spoilage, theft and tampering, as well as convenience in storing, distributing and transporting the item. The role of packaging can thus be divided into two functions namely, protecting the product and promoting the product (Hillstrom \& Hillstrom, 2002). In the case of evidence, the protection of the item is the essential function of packaging and should include safeguarding of the items against theft, damage, contamination and external conditions such as moisture, as well as the safety of the end-user, i.e. the analyst handling the evidence. 
Storage refers to the placement of goods in storage and includes the handling of materials to the assigned destinations for placement at these locations. Various criteria determine the viability of a storage area, for example storage layout and design. Helms (2006b) describes the layout as one of the most essential fundamentals that affects the efficiency with which the warehouse or storage area is managed. Gue (2006) states that effective utilisation of space can decrease total facility and operating cost, and lead to improved product flow and customer service. Every warehouse facility must be designed and laid out properly in order to maximise efficiency and productivity (Stock \& Lambert, 2001).

Connected with the physical handling and storage of goods should be an information control system. This should provide for the acknowledgement of receipt of goods, verifying the quality and quantity of the received items, updating inventory, locating the goods in storage, updating inventory when shipment takes place and referring to accounting services for billing (Rosaller, 2002). Using its EMS, the FSL ensures the continuous flow of information regarding evidence. The EMS facilitates the track and trace of evidence when determining its location within the laboratory and the progress of analysis. The judicial system is not connected to this system and information is obtained from analysts telephonically or via email. Computerised systems could have a major impact on the efficiency of the system. For example, an EDI system connecting the FSL with other judicial departments could increase efficiencies in the evidence supply chain.

Various types of storage equipment can be used to handle the flow of products within an area. According to Anderson (n.d.) the objectives when selecting a racking system for a warehouse include the maximisation of space utilisation, accessibility to items, equipment utilisation and protection of items. The FSL uses a ground level storage system, with little use of any racking.

Roodbergen, Gunter, Sharp and Iris (2008) describe order-picking as 'the warehousing process by which products are retrieved from their storage locations in response to customers' orders. Its efficiency can be influenced through the layout of the area and the operating policies.' Warehousing designers must bear this in mind when designing assembly areas (Roodbergen, et al. 2008). Order-picking is done by hand at the FSL, on request from the prosecutor. Inefficient picking, damages and theft can result in contamination of inventory items, thereby nullifying the usefulness of the goods to the judicial system.

Choi, Cao, Romeijn, Geunes and Bai (2005) recognise that effectively managing the inventory of multiple items, under conditions of limited warehouse storage capacity, is critical to ensure good customer service without incurring excessive inventory holding costs. In DNA storage, variables such as fluctuations in the flow of incoming evidence, the speed of analysis of evidence and the documenting of the findings at various levels or sections of the FSL need careful management. 
Malonis (2000) describes a feature of inventory cost as items that become obsolete or damaged or are stolen during storage. Although insurance normally covers these losses, in the case of evidence storage, damaged or contaminated evidence cannot be replaced in monetary terms and therefore its use to the judicial system becomes void. These costs of inventory holding will have a major impact on the supply chain costs and customer service.

Furthermore, the type of inventory items being held at the warehouse can also have an impact on the supply chain costs and operational requirements. When stored correctly, DNA evidence can be used for analysis decades after it was collected. Backlogs in cases received and finalised by the FSL therefore result in the DNA evidence being stored longer than it should, which has major cost implications in terms of storage space requirements and operational requirements such as labour and overhead costs. Furthermore deterioration or contamination can take place if the inventory is not managed according to the DNA storage requirements. This can result in a case being dismissed from court.

Installing the proper inventory control system can facilitate the effective use of the storage area and the easy identification of storage items, efficient housekeeping, space savings, and access to items. Inventory control systems are also implemented to ensure the sufficient flow of supplies and products. The stages of evidence inventories from the FSL perspective include storage from receipt, evidence kept in anticipation of requests from the prosecutor, and storage at the analyst. It is critical to ensure that inventories are managed correctly within the FSL to ensure that evidence is available at the exact moment it is required by the judicial system, which creates numerous complexities in the evidence inventory control system.

Agrawala (2009) explains that stock verification is the physical process of checking the items in storage and comparing the outcome with the quantities shown in the stock records. The implications of the variations can be costly in terms of inventory loss and customer service demands not being met, thus resulting in supply chain inefficiencies. At the FSL, verification of evidence goes beyond this as it could influence the outcome of a judicial case; it is therefore regarded as critical and done quarterly.

Marion (2001) identifies the importance of inventory security by suggesting the use of security systems such as alarms systems and closed circuit television. The recognition of the important role of security at the FSL is supported by the use of Biomatrix, a biometric system that tracks and traces the movement of evidence throughout the FSL. This eliminates unnecessary handling of evidence by unauthorised personnel and thus establishes the chain of evidence so critical to the judicial system.

The primary objective of any supply chain is to provide a service to its customer. A good indicator of customer service is when the item required is of a reasonable quality and available 
within a specified time. The customer service process should result in value addition to the product or service. The FSL, for example, provides a service specifically to the judicial system and thus to the public. Value-added services can include quality storage, reducing backlogs, speedy response, quick turn-around time and fast reliable analysis of evidence.

Gourdin (2006) reviews the organisation's customer service strategy in terms of the following five key concepts: dependability, time, convenience, communication and honesty. The FSL is required to ensure that all of these concepts are clearly adhered to, ensuring that the correct evidence is available when required by the judicial system, that the evidence is available with all the required information and technical assistance and that the evidence meets its customers' requirements - in particular having met the requirements of the Batho Pele concept, which includes communication with customers, establishing the client's need and expected standards of delivery, providing the necessary information required by the customer, and allowing customers to make suggestions and act upon them (Batho Pele Principles, 1997).

\section{STORAGE OF DNA EVIDENCE}

DNA evidence is stored within the FSL to facilitate its handling and analysis. Storage of evidence cannot be outsourced due to its sensitive nature and, according to South African law, the handling of evidence is restricted to police officials and FSL members (Hennop, 2009).

\section{Physical requirements}

DNA evidence is obtained from body fluid and is biological in nature. Degradation could take place due to factors such as fluctuation in temperature or failure to control the climate. At present there is a centralised air-conditioning system in place that regulates cooling and heating. It is extremely important to protect evidence against temperature fluctuation as it could compromise the evidence (Lerner \& Lerner, 2006c).

\section{Physical handling}

Body fluid stains must be considered as unknown entities, for example with regard to their source, and treated as bio-hazardous material. Viruses such as Hepatitis B and other illnesses can be present within the stain and personal protective equipment (PPE) must always be worn when DNA is handled.

Weapons come in all shapes, types and sizes. Weapons such as knives, broken bottles or any sharp instruments are a threat to the handler. Packaging and storage of these items must be done in such a way that no harm comes to the handler. The continuous integrity of the evidence must be protected throughout the correct storage and handling of evidence. 


\section{Packaging}

DNA can be found on various items. These items can differ in size and form and the packaging thereof is done in standardised packaging accepted by the judicial system (Hennop, 2009). Standardised evidence collection kits such as rape kits are used to collect DNA evidence from a person. All other evidence is collected and packaged in standard range evidencesealing bags. The sizes of these bags vary from envelope size to A1 (Hennop, 2009).

\section{Storage space}

The FSL has seven storage areas with shelving and a centralised air-conditioning system regulating the environment. This includes a 'walk-in' freezer where DNA samples are stored on a long-term basis. These storage areas are not strategically situated and can result in wastage. For example, the basement storage room is not equipped with a computerised system thereby hampering movement as well as the capturing of real-time information (Hennop, 2009). Evidence is placed according to availability of space, which is indicated by the EMS. The system only identifies open spaces and does not take into consideration the effort required from the analyst collecting the DNA from the different storage areas (Hennop, 2009).

\section{Information management systems}

The EMS tracks evidence from the point of origin to the point of departure. This enables the FSL and investigative officer to prove the chain of evidence, from collection at a crime scene to final documentation of findings at the FSL, should it be questioned in a court (Hennop, 2009).

The EMS is connected with the evidence from the time it is received until distribution and the records should be updated throughout the FSL process. This is accomplished through bar-coding while authentication is done through fingerprint identification/bio matrix. Realtime information can be provided if requested by the investigating officer or prosecutor. The EMS system also supports decision-making such as the categorisation of evidence according to the level of importance (Hennop, 2009).

The EMS is important should there be a dispute regarding the flow of evidence (Hennop, 2009). If a court official requests proof of the chain of evidence, the FSL needs to show that all quality measures had been adhered to, discrepancies were identified and reported, process details were recorded on the system and all information was verified.

Lerner and Lerner (2006d) identify the importance of a computerised system that is acknowledged by the judicial system; this also validates the analysed evidence in question. It is worthwhile noting that, while the EMS is used to track evidence within the chain of evidence, not all the evidence in the FSL is captured immediately. The basement storage 
rooms, for example, do not have computer facilities. When evidence is removed from this facility, there is a delay in updating the EMS, thereby creating potential gaps in the chain of evidence.

\section{Evidence exchange systems}

When a request is issued to analyse evidence, the Case Allocation Official (CAO) changes the status of the evidence to priority. The storage official retrieves the exhibits from a list sent by the CAO, scans all the barcodes, and both the CAO and analyst provide their fingerprint scans to verify and authenticate the transaction. Bio matrix (fingerprint identification) plays an important role in the FSL to rule out fraud and record the chain of evidence/custody (Hennop, 2009).

\section{Order picking}

The FSL order-picking process is a manual procedure. The DNA is collected by the analyst dealing with a specific case, thus excluding any unauthorised handling. DNA evidence is processed when requisitioned by a prosecutor. This ensures that analysis takes place and the report is available for the set court date, thereby eliminating waste of time and resources. This also prevents the case from being postponed or rejected by the court (Hennop, 2009).

\section{Inventory management}

Inventory management is also a critical warehousing function in the FSL to ensure the chain of evidence. Quarterly bar-coding checks are done to prevent misplacement and loss of evidence. All information is available on the EMS system and evidence can be traced at any point and the chain of evidence established from reception at the FSL until distribution of evidence. Inventory management confirms the evidence in storage and enables the DNA analysis process (Hennop, 2009).

\section{Customer service}

Processing of evidence and delivery of analysis normally takes place only after a request from the prosecutor. The FSL also provides interim information when required by the prosecutor or investigating officer. Currently the FSL is required to complete $92 \%$ of all cases within 35 days thus requiring a faster order cycle time. This period is calculated from the time the DNA is allocated to an analyst until the final report is composed (Hennop, 2009). Communication between the FSL and the National Prosecuting Authority (NPA) takes place on a regular basis to identify the customers' needs.

The need to reduce backlogs was identified by Mlambo-Ngcuka (2007): 'Government is further intent on improving the functioning of the criminal justice system. This relates to the need to reduce the backlog of cases pending trial or finalisation, reducing case cycle times and generally making our courts more efficient'. Backlogs can influence customer service negatively. 
Customer service is a critical facet of an organisation trying to offer the highest standard of service delivery at the lowest possible cost. Government's Batho Pele Principles (DPSA, n.d.) to improve service delivery in the public sector, encourage open communication between departments and customers to identify the customers' needs, offering a valueadded service delivery at the right time. A customer service focus is critical to the FSL in attempting to deliver a faster turn-around time, as agreed with the NPA.

\section{CONCLUSIONS AND RECOMMENDATIONS}

The use of DNA evidence has increased in recent years as an important tool to identifying suspects and setting the innocent free. The function of the FSL Biology Section is to assist the police and judicial system by storing and analysing DNA and presenting the findings in court. Storage of evidence must, first, meet certain criteria to prevent contamination and safeguard evidence. Secondly, the evidence must have a documented path, also called the chain of evidence to prove to the court, if required, that the integrity of the evidence is legitimate.

Continuous improvement and best practice in forensic laboratories is required due to customer requirements and the challenges of improved technology and the innovativeness of suspects. However, mistakes made at any stage of the evidence supply chain can affect the outcomes of the judicial system.

Based on the preceding discussions, the following recommendations are made to increase the effectiveness of the FSL as a storage facility:

\section{Centralisation of storage facilities}

The existing storage facilities at the FSL include storage rooms at various levels within the FSL building. DNA evidence is allocated according to the availability of space within these storage rooms.

Changing the storage facilities to a centralised facility could collect all the processes in the forensic departments and storage facilities into one area. This would eliminate unnecessary movement and handling of evidence, for example, evidence destined for more than one forensic section can easily be transferred internally with minimum handling. Forensic tests and procedures could therefore be carried out faster and more efficiently. This would improve the overall output and, through proper co-ordination and management, could prove valuable to all users, including investigators, forensic scientists and courts. Note however that a major disadvantage of establishing a centralised warehouse is the initial capital expenditure. 


\section{Utilisation of storage space and equipment}

The use of storage space should be managed to ensure rapid and easy movement of evidence from point-of-arrival to point-of-departure. Proper planning of the space and processes will ensure easy identification and movement of evidence and this will result in a functional evidence warehouse and will prevent loss of time and inefficient use of labour, equipment and space.

The storage racks at the present FSL facility cannot be optimally utilised due to the standardised sealing bags. The bags cannot be stacked and therefore take up too much space. Furthermore, the bags are flimsy and storage cannot be planned beforehand as the package may be too big for the available space. This results in unnecessary movement of evidence between storage areas. Shelving should be installed from floor to ceiling as is done in the storage methods used in the USA. This would enable a far better utilisation of the available storage space compared to the current system of floor storage, thus enabling far greater efficiencies within the system. Containers such as boxes could be used to store all evidential pieces per case including the case file thereby utilising the space more efficiently and reducing the risk of damage and subsequent contamination of evidence.

The warehouse could also be fitted with a climate control system to ensure the integrity of the DNA evidence. A climate control system automatically adjusts the cooling or heating of a storage area, independent of outside environmental conditions.

\section{Information technology}

Due to the lack of appropriate storage space, the allocation of cases potentially requires the analyst to pick evidence from six different storage areas (excluding the 'walk-in' freezer) within the FSL building, which results in significant time expenditure. The basement storage area does not have computer facilities to immediately capture the movement of the DNA evidence in the EMS. Information gaps between the investigator-warehouse-judicial systems can be costly in terms of solving or finalising cases. Accurate information influences the success of the warehouse. Therefore, computerised systems are an important investment for the FSL as well as the judicial system.

\section{Layout and design}

A centralised receiving area should be planned in such a way that it allows the evidence to flow in an orderly manner. At present, evidence is stored where there is available space, with little regard for logical groupings of cases or types of evidence. Consideration must be given to the different types of evidence that will move through the receiving area, and handling of evidence must be planned to prevent time loss and increase productivity. 
It is critical to design a cost-efficient warehouse where people can function effectively and efficiently. The warehouse should be designed in such a way that alterations could be made if growth and future changes take place. Effectiveness will depend on whether the design is user-friendly as this will increase output and improve the flow of information. All this can result in increased efficiency and service and cost savings for the judicial system.

\section{DNA training}

The SAPS, when collecting evidence, do not always take appropriate care in protecting DNA evidence. The need therefore arises to provide education and training for all parties involved in the collection of evidence and the safeguarding thereof through the chain of evidence. This would also lead to the optimal of the FSL and the DNA evidence stored and analysed therein.

\section{Summary}

In summary, the FSL will continue providing an excellent service to its internal and external customers. However, implementing the abovementioned recommendations would lead to a number of improvements. The working conditions would improve and storage of evidence would be centralised thus saving time and costs in storing DNA evidence for analysis. The proposed changes to the FSL would improve access to evidence, and prevent deterioration, tampering and other possible damage, thus meeting the customer service requirements agreed with the NPA and adding value to the judicial system overall. 


\section{REFERENCES}

Agrawala, K. 2009. What is stock verification in relation to spare parts management and their function, objectives and procedures? Available from: eNotes.com. 2009. http://www. enotes.com/business/q-and-a/what-stock-verification-relation-spare-parts 84663 (Accessed 24 June 2009).

Anderson, L. (n.d.). Increase your productivity and maximise your warehouse space with pallet racks. Available from: ezine@rticles.com. http://www.earticles.com/? IncreaseYour-Productivity-and-Maximize-Your-Warehouse-Space-With-Pallet-Racks\&id=3170983 (Accessed 24 June 2009).

Anonymous. 2003. DNA evidence: What law enforcement officers should know. NIJ Journal. Issue No. 249, July 2003. Available from: http://www.ncjrs.gov/pdffiles1/jr000249c.pdf. (Accessed 8 July 2009).

Batho Pele Principles. 1997. Government Gazette, Vol 388, No 18340. Available from:Government Gazette http://www.info.gov.za/whitepapers/1997/18340.pdf. (Accessed 8 July 2009).

Bennet, W \& Hess, K.M. 2004. Criminal Investigation. Thomson Wadsworth.

Brockman, T. 1999. 21 Warehousing trends in the 21st century. Available from: allbusiness. com.http://www.allbusiness.com/company-activities management/operations-supply-chain/ 7339221-1.html (Accessed 24 June 2009).

Choi, J., Cao, J., Romeijn, H.E., Geunes, J. \& Bai, S.X. 2005. A stochastic multi-item inventory model with unequal replenishment intervals and limited warehouse capacity. IIE Transactions. 37(12), 1129-42. Available from: Academic OneFile.Gale. http://0-find. galegroup.com.ujlink.uj.ac.za/ips/start.do?prodld=IPS. (Accessed 29 July 2009).

Coetzee, B. \& Horn, R. 2007. Theft of precious metals from South African mines and refineries. Monograph No 133. (May 2007). Available from: Institute for security studies.http://www. issafrica.org/index.php?link_id=3\&slink_id=4793\&link_type=12\&s ink type=12\&tmpl_id=3 (Accessed 23 June 2009).

DNA Initiative. (n.d.) Advancing criminal justice through DNA technology, Compromised evidence. Available from: http://www.dna.gov/research/compromised_evidence. (Accessed 13 June 2009). 
DPSA Batho Pele Principles (n.d.) Available from: South African government website http:// www.dpsa.gov.za/batho-pele/Principles.asp (Accessed 8 July 2009).

Evert, Inspector. Personal communication. 22 February 2008.

Fowler, S. 2006. A crime scene investigator in the police force. Biological Sciences Review. 18.3(Feb 2006):38(4). Available from: Academic OneFile. Gale. Gale Document Number:A142058292.http://Ofind.galegroup.com.ujlink.uj.ac.za:80/ips/start. do?prodld=IPS (Accessed 24 June 2009).

Gourdin, K.N. 2006. Global logistics management. 2nd edition. Malden: Blackwell Publishing.

Grant, D.B., Lambert, D.M., Stock, J.R. \& Ellram, L.M. 2006. Fundamentals of Logistics Management, McGraw-Hill: Maidenhead.

Gue, K.R. 2006. Very high density storage systems. IIE Transaction. Available from: Academic OneFile. Gale. http://Ofind.galegroup.com.ujlink.uj.ac.za/ips/start.do?prodld=IPS. (Accessed 12 December 2008).

Hails, J. 2005. Criminal evidence. 5th edition. California: Thomson Wadsworth.

Helms, M.M. (Editor). 2006a. Warehousing and warehouse management. Encyclopaedia of Management. Gale Cengage, 2006. Available from: eNotes.com. 2006. http://www. enotes.com/management-encyclopedia/warehousing-warehouse management. (Accessed 24 June 2009).

- 2006b. Layout. Encyclopaedia of Management. Gale Cengage, 2006. Available from: eNotes.com. 2006. http://www.enotes.com/management-encyclopedia/layout (Accessed 24 June 2009).

Hennop, P. 2009. Personal communication.

Heragu, S.S., Cai, X., Krishnamurthy, A. \& Malmborg, C.J. 2008. Striving for warehouse excellence: Savvy material handling tools are helping in Europe. Industrial Engineer 40.12 (Dec 2008): 43(5). Available from: Academic OneFile. Gale. http://0-find.galegroup.com. ujlink.uj.ac.za:80/ips/start.do?prodld=IPS. (Accessed 12 December 2008).

Hillstrom, K. (Editor) \& Hillstrom, L.C. 2002. Packaging. Encyclopaedia of Small Business. Gale Cengage, 2002. Available from: eNotes.com. 2006. http://www.enotes.com/smallbusiness-encyclopedia/packaging (Accessed 24 June 2009). 
Lee, S.B. \& Roberts, K.A. 2008. 'Saving your samples.' Emerging technologies in forensic science, 01/08. Available from: http://www.biomatrica.com/media/articles/0008.pdf. (Accessed 1 August 2009).

Lehman, J. \& Phelps, S. 2005. DNA evidence. West's Encyclopaedia of American Law. 2nd edition. Gale Cengage.

Lerner, K.L. (Editor) \& Lerner, B.W. 2006a. Evidence. World of Forensic Science. Gale Cengage, 2006. Available from: eNotes.com. 2006. http://www.enotes.com/forensicscience/evidence. (Accessed 8 July 2009).

- 2006b. Evidence, chain of custody. World of Forensic Science. Gale Cengage, 2006. Available from: eNotes.com. 2006. http://www.enotes.com/forensic-science/evidencechain-custody. (Accessed 8 July 2009).

- 2006c. Disturbed evidence. World of Forensic Science. Gale Cengage, 2006. Available from: eNotes.com. 2006. http://www.enotes.com/forensic-science/disturbed-evidence. (Accessed 8 July 2009).

- 2006d. Quality control of forensic evidence. World of Forensic Science. Gale Cengage, 2006. Available from: eNotes.com. 2006. http://www.enotes.com/forensic-science/qualitycontrol-forensic-evidence (Accessed 8 July 2009).

Malonis, A. (Editor). 2000. Business logistics. Encyclopaedia of Management. Gale Cengage, 2000. Available from: eNotes.com. 2006. http://www.enotes.com/biz-encyclopedia/ business-logistics. (Accessed 24 June 2009).

Marion, A.M. (Editor). 2001. Inventory control. Encyclopaedia of Business and Finance. Gale Cengage, 2001. Available from: eNotes.com. 2006. http://www.enotes.com/businessfinance-encyclopedia/inventory-control. (Accessed 24 June 2009).

Mlambo-Ngcuka, P.2007. Oral replyin NationalAssembly.28/02/2007.Availablefrom:Polityhttp:// www.polity.org.za/article/mlambongcuka-oral-reply-in-national-assembly-28022007-2007-02-28 (Accessed 30 April 2008).

Roodbergen, K.J., Sharp, G.P. \& Iris F.A. 2008. Designing the layout structure of manual order picking areas in warehouses. IIE Transactions 40.11. Nov 2008:1032(14). Available from: Academic OneFile. Gale. http://O-find.galegroup.com.ujlink.uj.ac.za/ips/start. do?prodld=IPS. (Accessed 12 December 2008). 
Rosaller R. 2002. Standard handbook of plant engineering. 3rd edition. McGraw Hill

SCCJA. (n.d.) Crime scene response and physical evidence. Federal Bureau of Investigation. US Department of Justice. Handbook of Forensic Science. Washington, DC: US Government Printing Office. Available from: http://www.sccja.org/csr.htm. (Accessed 18 January 2009)

Stock, J.R. \& Lambert, D.M. 2001. Strategic logistics management. 4th edition. New York: McGraw-Hill.

Vasiliu, C. 2008. Warehousing activity which contributes to supply chain performance. The Amfiteatru Economic Journal. Available from: Econpapers http://econpapers.repec. org/article/aesamfeco/v_3a10_3ay_3a2008_3ai_3a24_3ap_a94-108.htm. (Accessed 12 December 2008).

Zandin, K.B. 2001. Maynard's industrial engineering handbook [electronic resource] New York: McGraw Hill. 